\title{
Determinan Keputusan Pekerja Mandiri menjadi Peserta Jaminan Kesehatan Nasional
}

\author{
Jumatra Laila, Asmaripa Ainy ${ }^{\star}$, Dian Safriantini \\ Fakultas Kesehatan Masyarakat Universitas Sriwijaya \\ *Corresponding author, e-mail: asmaripa_ainy@fkm.unsri.ac.id
}

Received: 30/05/2019; published: 12/02/2020

\begin{abstract}
Background: National health insurance is mandatory for all Indonesians. In Ogan llir Regency, the lowest percentage $(24,14 \%)$ of its participants in December 2016 was found in Indralaya Utara Sub-district, and self-employed participants in this sub-district were only 6,99\%. This study aimed to analyze the determinants of the self-employed's decision to become national health insurance participants in Indralaya Utara Sub-district. Method: This was a cross-sectional study. The population was self-employed in Indralaya Utara Sub-district. The sample was 108 respondents who were selected using cluster sampling and consecutive sampling techniques. Data analysis was conducted by univariate and bivariate with chi-square statistical test. Results: The results illustrated that $18,52 \%$ of respondents decided to become national health insurance participants. Variables with $p$-value $<0,005$ were: knowledge about national health insurance $(p$-value $=0,011)$, trust ( $p$-value $=0.000)$, perception about national health insurance ( $p$-value $=0,000)$, attitude $(p$ value $=0,000)$, income ( $p$-value $=0,002)$, family support ( $p$-value $=0,005)$. Variables with $p$ value $\geq 0,005$ were: education ( $p$-value $=0,234)$, perception about health facilities ( $p$-value $=0,162)$, distance to health facilities ( $p$-value $=0,355)$, health workers support ( $p$-value $=0,112$ ). Conclusion: In conclusion, percentage of self-employed who decided become national health insurance participants was still small. Associated factors to the decision of self-employed as participants were: knowledge about national health insurance, trust, perception about national health insurance, attitude, income and family support. It is suggested that the Social Security Administrative Body for Health should routinely conduct socialization on national health insurance to improve the percentage of its participation for self-employed and the benefits of national health insurance could be felt by the entire community.
\end{abstract}

Keywords: self-employed; national health insurance; universal health coverage

Copyright $\left({ }^{\circ} \quad\right.$ Universitas Ahmad Dahlan. All rights reserved.

1. Pendahuluan

Program Jaminan Kesehatan Nasional (JKN) yang dikembangkan di Indonesia merupakan bagian dari Sistem Jaminan Sosial Nasional (SJSN) yang diselenggarakan oleh Badan Penyelenggara Jaminan Sosial (BPJS) melalui mekanisme asuransi sosial.(1) Badan Penyelenggara Jaminan Sosial yang dimaksud berbentuk badan hukum dan untuk jaminan kesehatan diselenggarakan oleh BPJS Kesehatan.(2) Lebih lanjut, Peraturan Presiden nomor 111 tahun 2013 pasal 6 menjelaskan bahwa kepesertaan Jaminan Kesehatan bersifat wajib dan mencakup seluruh penduduk Indonesia.(3) Hal ini sesuai dengan kebijakan Pemerintah Indonesia yaitu jaminan kesehatan semesta (Universal Health Coverage/UHC) yang menargetkan bahwa di tahun 2019 seluruh penduduk Indonesia sudah menjadi peserta Jaminan Kesehatan Nasional. Pemerintah Sumatera Selatan ikut mendukung kebijakan tentang JKN tersebut yang ditunjukkan dengan upaya dari pengelola Jaminan Kesehatan Daerah Sumatera Selatan (Jamsoskes) terkait perluasan kepesertaan JKN melalui koordinasi dengan BPJS Kesehatan mengenai data jumlah peserta JKN dengan kategori 
Penerima Bantuan luran (PBI) atau jumlah peserta JKN di Provinsi Sumatera Selatan yang dijamin oleh pemerintah.

Berdasarkan data cakupan JKN, proporsi penduduk Indonesia yang terdaftar menjadi peserta JKN per 31 Desember 2017 adalah 187.982 .949 jiwa dari total penduduk lebih dari 255 juta jiwa.(4) Jumlah peserta yang terdaftar sebagai peserta JKN di Indralaya Utara belum mencapai target $100 \%$. Berdasarkan data kepesertaan jaminan kesehatan per Desember 2016, cakupan kepesertaan JKN di wilayah Kabupaten Ogan Ilir, Sumatera Selatan masih rendah $(47,15 \%)$. Persentase cakupan kepesertaan paling rendah dijumpai di Kecamatan Indralaya Utara yakni sebesar $24,14 \%$ dari total 36.540 jiwa, yang terdiri dari peserta Penerima Bantuan luran (PBI) 17,15\% dan peserta Non Penerima Bantuan Iuran (Non PBI) atau mandiri 6,99\%.(5)

Jaminan kesehatan nasional diharapkan dapat menjangkau ke peserta lain yang lebih luas serta memberikan manfaat yang lebih besar bagi setiap peserta sehingga terwujud kesejahteraan bagi seluruh masyarakat Indonesia.(6) Salah satu peserta yang bisa ditingkatkan jumlahnya dalam pencapaian universal health coverage pada tahun 2019 adalah kelompok pekerja bukan penerima upah (PBPU) atau pekerja mandiri.(7) Proporsi pekerja mandiri mendominasi angkatan kerja di Indonesia tetapi mereka belum sepenuhnya tercover sistem jaminan kesehatan nasional.(8) Oleh karena itu, perlu dilakukan penelitian untuk mengetahui determinan keputusan pekerja mandiri untuk menjadi peserta jaminan kesehatan nasional di Kecamatan Indralaya Utara.

\section{Metode}

Penelitian ini menggunakan metode kuantitatif dengan desain penelitian crosssectional. Populasi penelitian adalah seluruh pekerja mandiri yang ada di Kecamatan Indralaya Utara dan sampel adalah kepala keluarga pekerja mandiri di wilayah Kecamatan Indralaya Utara yang berjumlah 108 responden, yang diperoleh dari penghitungan besar sampel minimal menggunakan rumus dua proporsi populasi dengan penambahan $10 \%$ untuk menghindari sampel drop out. Sampel dipilih menggunakan teknik cluster random sampling dan consecutive sampling. Teknik cluster random sampling dilakukan dengan membagi sampel menggunakan kelompok subjek yang dipilih secara random. Pada penelitian ini, kelompok subjek dipilih berdasarkan desa yang ada di Kecamatan Indralaya Utara. Ada 4 desa yang terpilih yaitu: Pulau Semambu, Timbangan, Suka Mulia, dan Permata Baru. Selanjutnya dari desa yang terpilih, ditentukan sampel yang memenuhi kriteria penelitian berjumlah 108 responden.

Jenis data dalam penelitian ini adalah data primer dan sekunder. Pengumpulan data primer dilakukan dengan wawancara menggunakan kuesioner. Variabel dependen adalah: pendidikan, pengetahuan mengenai JKN, kepercayaan, persepsi mengenai JKN, sikap, persepsi mengenai fasilitas kesehatan, pendapatan, jarak tempuh ke fasilitas kesehatan, dukungan keluarga, dan dukungan petugas. Sedangkan variabel independen adalah keputusan menjadi peserta JKN. Data dianalisis secara univariat dan bivariat dengan uji statistik chi-square, kemudian disajikan dalam bentuk tabel, selanjutnya hasil akhir dari datadata tersebut diinterpretasikan.

\section{Hasil dan Pembahasan}

3.1. Hasil

Hasil yang disajikan pada Tabel 1. menunjukkan bahwa dari 108 responden pekerja mandiri yang memutuskan menjadi peserta JKN (18,52\%). Hal ini berarti bahwa mayoritas responden belum menjadi peserta JKN. Mayoritas pekerja mandiri memiliki pendidikan tinggi $(55,56 \%)$ dengan pengetahuan tinggi mengenai JKN $(58,33 \%)$ dan kepercayaan yang tinggi juga $(54,63 \%)$. Dilihat dari persepsi pekerja mandiri terhadap JKN, mayoritas responden memiliki persepsi yang negatif terhadap JKN $(63,89 \%)$, persepsi negatif pekerja mandiri ini diikuti juga dengan sikap yang negatif $(56,48 \%)$ dan persepsi negatif tentang fasilitas 
kesehatan $(56,48 \%)$. Rata-rata responden memiliki pendapatan yang rendah $(58,33 \%)$, $(81,48 \%)$ pekerja mandiri menyatakan bahwa jarak tempuh rumah ke fasilitas kesehatan adalah dekat. Mayoritas pekerja mandiri mendapatkan dukungan yang rendah baik dari keluarga $(55,56 \%)$ maupun petugas kesehatan $(58,33 \%)$.

Tabel 1. Distribusi Frekuensi Keputusan Pekerja Mandiri Menjadi Peserta JKN di Kecamatan Indralaya Utara

\begin{tabular}{|c|c|c|}
\hline \multirow[t]{2}{*}{ Variabel } & \multicolumn{2}{|c|}{ Total Responden } \\
\hline & $\mathbf{n}$ & $\%$ \\
\hline \multicolumn{3}{|c|}{ Keputusan menjadi peserta JKN } \\
\hline Peserta & 20 & 18,52 \\
\hline Non peserta & 88 & 81,48 \\
\hline \multicolumn{3}{|l|}{ Pendidikan } \\
\hline Tinggi & 60 & 55,56 \\
\hline Rendah & 48 & 44,44 \\
\hline \multicolumn{3}{|c|}{ Pengetahuan mengenai JKN } \\
\hline Tinggi & 63 & 58,33 \\
\hline Rendah & 45 & 41,67 \\
\hline \multicolumn{3}{|l|}{ Kepercayaan } \\
\hline Tinggi & 59 & 54,63 \\
\hline Rendah & 49 & 45,37 \\
\hline \multicolumn{3}{|c|}{ Persepsi mengenai JKN } \\
\hline Positif & 39 & 36,11 \\
\hline Negatif & 69 & 63,89 \\
\hline \multicolumn{3}{|l|}{ Sikap } \\
\hline Positif & 47 & 43,52 \\
\hline Negatif & 61 & 56,48 \\
\hline \multicolumn{3}{|c|}{ Persepsi mengenai fasilitas kesehatan } \\
\hline Positif & 47 & 43,52 \\
\hline Negatif & 61 & 56,48 \\
\hline \multicolumn{3}{|l|}{ Pendapatan } \\
\hline Tinggi & 45 & 41,67 \\
\hline Rendah & 63 & 58,33 \\
\hline \multicolumn{3}{|c|}{ Jarak tempuh ke fasilitas kesehatan } \\
\hline Dekat & 88 & 81,48 \\
\hline Jauh & 20 & 18,52 \\
\hline \multicolumn{3}{|l|}{ Dukungan keluarga } \\
\hline Tinggi & 48 & 44,44 \\
\hline Rendah & 60 & 55,56 \\
\hline \multicolumn{3}{|l|}{ Dukungan petugas } \\
\hline Tinggi & 45 & 41,67 \\
\hline Rendah & 63 & 58,33 \\
\hline
\end{tabular}

Hasil yang disajikan pada Tabel 2. menunjukkan bahwa adanya hubungan antara variabel pengetahuan mengenai JKN $(95 \% \mathrm{Cl}=1,415-18,922$; $p$-value $<0,05)$, kepercayaan $(95 \% \mathrm{Cl}=2,257-47,159 ; p$-value $<0,05)$, persepsi mengenai JKN $(95 \% \mathrm{Cl}=4,547-63,563 ; p$ value $<0,05)$, sikap $(95 \% \mathrm{Cl}=3,977-84,307 ; p$-value $<0,05)$, pendapatan $(95 \% \mathrm{Cl}=1,923$ $17,493 ; p$-value $<0,05)$ dan dukungan keluarga $(95 \% \mathrm{Cl}=1,664-15,025 ; \quad p$-value $<0,05)$ dengan keputusan pekerja mandiri menjadi peserta JKN di Kecamatan Indralaya Utara. Sedangkan variabel yang tidak berhubungan dengan keputusan pekerja mandiri menjadi peserta JKN di Kecamatan Indralaya Utara yaitu pendidikan $(95 \% \mathrm{Cl}=0,750-6,051 ; p$ value $\geq 0,05)$, persepsi mengenai fasilitas kesehatan $(95 \% \mathrm{Cl}=0,842-6,120 ; p$-value $\geq 0,05)$, jarak tempuh ke fasilitas kesehatan $(95 \% \mathrm{Cl}=0,491-10,903 ; p$-value $\geq 0,05)$ dan dukungan petugas $(95 \% \mathrm{Cl}=0,926-6,750 ; p$-value $\geq 0,05)$. 
Tabel 2. Analisis Bivariat Keputusan Pekerja Mandiri Menjadi Peserta JKN di Kecamatan Indralaya Utara

\begin{tabular}{|c|c|c|c|c|c|c|c|}
\hline \multirow{3}{*}{ Variabel } & \multicolumn{4}{|c|}{$\begin{array}{l}\text { Keputusan menjadi } \\
\text { peserta JKN }\end{array}$} & \multirow{3}{*}{$\mathbf{N}$} & \multirow{3}{*}{$\begin{array}{c}P \text { - } \\
\text { value }\end{array}$} & \multirow{3}{*}{ PR (95\%Cl) } \\
\hline & \multicolumn{2}{|c|}{ Peserta } & \multicolumn{2}{|c|}{ Non peserta } & & & \\
\hline & $\mathbf{n}$ & $\%$ & $\mathbf{n}$ & $\%$ & & & \\
\hline \multicolumn{8}{|l|}{ Pendidikan } \\
\hline Tinggi & 14 & 23,33 & 46 & 76,67 & 60 & \multirow{2}{*}{0,234} & \multirow{2}{*}{$(0,750-6,051)$} \\
\hline Rendah & 6 & 12,50 & 42 & 87,50 & 48 & & \\
\hline \multicolumn{8}{|l|}{ Pengetahuan mengenai } \\
\hline JKN & 17 & 26,98 & 46 & 73,02 & 63 & \multirow{2}{*}{0,011} & \multirow{2}{*}{$\begin{array}{c}5,174 \\
(1,415-18,922)\end{array}$} \\
\hline $\begin{array}{l}\text { Tinggi } \\
\text { Rendah }\end{array}$ & 3 & 6,67 & 42 & 93,33 & 45 & & \\
\hline \multicolumn{8}{|l|}{ Kepercayaan } \\
\hline Tinggi & 18 & 30,51 & 41 & 69,49 & 59 & \multirow[t]{2}{*}{0,000} & \multirow{2}{*}{$\begin{array}{c}10,317 \\
(2,257-47,159)\end{array}$} \\
\hline Rendah & 2 & 4,08 & 47 & 95,92 & 49 & & \\
\hline \multicolumn{8}{|l|}{ Persepsi mengenai JKN } \\
\hline Positif & 17 & 43,59 & 22 & 56,41 & 39 & \multirow{2}{*}{0,000} & \multirow{2}{*}{$\begin{array}{c}17,000 \\
(4,547-63,563)\end{array}$} \\
\hline Negatif & 3 & 4,35 & 66 & 95,65 & 69 & & \\
\hline \multicolumn{8}{|l|}{ Sikap } \\
\hline Positif & 18 & 38,30 & 29 & 61,70 & 47 & \multirow[t]{2}{*}{0,000} & \multirow{2}{*}{$\begin{array}{c}18,310 \\
(3,977-84,307)\end{array}$} \\
\hline Negatif & 2 & 3,28 & 59 & 96,72 & 61 & & \\
\hline \multicolumn{8}{|l|}{ Persepsi mengenai } \\
\hline fasilitas kesehatan & 12 & 25,53 & 35 & 74,47 & 47 & \multirow{2}{*}{0,162} & \multirow{2}{*}{$\begin{array}{c}2,271 \\
(0,842-6,120)\end{array}$} \\
\hline $\begin{array}{l}\text { Positif } \\
\text { Negatif }\end{array}$ & 8 & 13,11 & 53 & 86,89 & 61 & & \\
\hline \multicolumn{8}{|l|}{ Pendapatan } \\
\hline Tinggi & 15 & 33,33 & 30 & 66,67 & 45 & \multirow[t]{3}{*}{0,002} & \multirow{3}{*}{$\begin{array}{c}5,800 \\
(1,923-17,493)\end{array}$} \\
\hline Rendah & 5 & 7,94 & 58 & 92,06 & 63 & & \\
\hline \multicolumn{6}{|l|}{$\begin{array}{l}\text { Jarak tempuh ke fasilitas } \\
\text { kesehatan }\end{array}$} & & \\
\hline kesehatan & 18 & 20,45 & 70 & 79,54 & & 0,355 & 2,314 \\
\hline $\begin{array}{l}\text { Dekat } \\
\text { Jauh }\end{array}$ & 2 & 10,00 & 18 & 90,00 & 20 & & $(0,491-10,903)$ \\
\hline Dukungan keluarga & & & & & & & \\
\hline Tinggi & 15 & 31,25 & 33 & 68,75 & 48 & 0,005 & 5,000 \\
\hline Rendah & 5 & 8,33 & 55 & 91,67 & 60 & & $(1,664-15,025)$ \\
\hline Dukungan petugas & & & & & & & \\
\hline Tinggi & 12 & 26,67 & 33 & 73,33 & 45 & 0,112 & $\begin{aligned} 2,500 \\
0\end{aligned}$ \\
\hline Rendah & 8 & 12,70 & 55 & 87,30 & 63 & & $(0,926-6,150)$ \\
\hline
\end{tabular}

\subsection{Pembahasan}

Hasil analisis menunjukkan bahwa sangat sedikit pekerja mandiri yang memutuskan menjadi peserta JKN. Perluasan kepesertaan JKN membutuhkan peran lintas sektor. Hasil peneliti lainnya menunjukkan pentingnya koordinasi lintas sektor dalam bentuk kemitraan tetapi masih terkendala dengan kejelasan pembagian peran masing-masing pihak dan sikap belum yakin bahwa UHC akan tercapai di tahun 2019.(9) Rendahnya kepesertaan JKN di kalangan pekerja mandiri di Kecamatan Indralaya Utara disebabkan oleh responden yang tidak pernah mendapatkan sosialisasi tentang JKN sehingga mereka belum memahami secara mendalam mengenai paket layanan kesehatan peserta JKN dan belum merasakan manfaat yang besar jika mendaftar menjadi peserta JKN. Penelitian serupa juga menyatakan bahwa kurangnya sosialisasi dan kurangnya media promosi kesehatan merupakan akar penyebab masalah rendahnya kepesertaan JKN sektor informal di wilayah pedesaan.(10) Sehingga perlu ada strategi dan media sosialisasi yang tepat untuk memberikan informasi mengenai JKN kepada masyarakat pekerja mandiri.

Hasil penelitian menunjukkan bahwa persepsi yang negatif dari responden mencakup kerumitan prosedur pendaftaran dan pelayanan kesehatan JKN serta sikap tenaga kesehatan yang lebih mengutamakan pasien non JKN dari pada pasien JKN. Selain itu, 
dukungan keluarga juga menjadi penyebab rendahnya persentase pekerja mandiri memutuskan menjadi peserta JKN. Mayoritas pekerja mandiri yang memutuskan menjadi peserta JKN adalah yang mendapatkan dukungan tinggi dari keluarga. Masyarakat yang mempunyai pengetahuan rendah terhadap JKN tetapi mendapatkan dukungan yang baik dari keluarga mampu meningkat motivasinya untuk mendaftarkan diri menjadi peserta JKN.

Pendidikan merupakan salah satu faktor yang dapat mempengaruhi perilaku kesehatan seseorang. Tingkat pendidikan seseorang berperan penting terhadap kepesertaan JKN karena dapat mempengaruhi tindakan untuk mengatasi resiko ketidakpastian di masa depan.(11) Hasil penelitian menunjukan tidak ada hubungan antara pendidikan dengan keputusan pekerja mandiri menjadi peserta JKN. Peneliti berpendapat tidak adanya hubungan dikarenakan pendidikan merupakan faktor yang sulit diintervensi. Tingkat pemahaman seseorang tidak hanya diperoleh dari pendidikan secara formal saja tetapi juga dapat diperoleh melalui pendidikan non formal serta pemanfaatan teknologi informasi untuk memperoleh informasi apa pun dengan cepat. Peningkatan pemahaman kelompok masyarakat dapat dilakukan melalui sosialisasi dan koordinasi mengenai JKN oleh BPJS Kesehatan kepada instansi terkait yakni: dinas kesehatan, puskesmas serta rumah sakit pemerintah serta penyampaian informasi melalui media televisi.(12)

Berdasarkan hasil penelitian menunjukan bahwa terdapat hubungan antara pengetahuan mengenai JKN dengan keputusan pekerja mandiri menjadi peserta JKN. Hal ini karena dengan pengetahuan yang baik akan membawa seseorang untuk bertindak dan bersikap yang baik juga. Hasil penelitian serupa mengkaji bahwa ketersediaan media informasi dan sosialisasi tentang JKN hanya di tempat tertentu saja khususnya di area sekitar fasilitas kesehatan menjadi penyebab rendahnya pengetahuan masyarakat.(13) Kemudian hasil penelitian juga menunjukkan bahwa ada hubungan antara kepercayaan dengan keputusan pekerja mandiri menjadi peserta JKN. Menurut peneliti adanya hubungan karena kepercayaan merupakan penguat ketertarikan seseorang terhadap suatu objek. Seseorang yang percaya terhadap program JKN akan lebih tertarik dan berminat untuk memutuskan menjadi peserta JKN. Penelitian serupa membuktikan bahwa kepercayaan timbul karena adanya pengalaman keluarga terhadap pemanfaatan layanan pengobatan tradisional.(14) Kepercayaan juga merupakan aspek yang berkaitan dengan kehidupan masyarakat Indonesia dan diperlukan sebagai upaya peningkatan kesadaran masyarakat.(15) Lebih lanjut, aspek kepercayaan dari penelitian ini yang perlu menjadi perhatian yaitu kepercayaan mengenai pelayanan yang adil antara pasien peserta JKN dengan pasien non peserta JKN. Maka diperlukan persuasi oleh institusi penyelenggaran layanan kesehatan baik milik pemerintah maupun swasta untuk memberikan efek peningkatan kepercayaan masyarakat menjadi peserta program JKN-KIS.(16)

Jaminan kesehatan belum dirasa menjadi kebutuhan penting bagi peserta mandiri sehingga perluasan kepesertaan JKN masih mengalami kendala.(17) Berdasarkan hasil penelitian ini, banyak pekerja mandiri yang tidak terdaftar atau belum terdaftar menjadi peserta JKN yang memiliki persepsi negatif terhadap JKN. Hasil analisis menunjukan bahwa terdapat hubungan antara persepsi dengan keputusan pekerja mandiri menjadi peserta JKN di Kecamatan Indralaya Utara. Beberapa hal yang perlu menjadi perhatian yaitu persepsi mengenai iuran JKN yang mahal, prosedur pelayanan kesehatan pasien JKN yang rumit, tenaga kesehatan lebih mengutamakan pasien peserta non JKN dibandingkan peserta JKN saat berobat, pendaftaran menjadi peserta JKN rumit dan prosedur pelayanan kesehatan pasien peserta JKN rumit. Sejalan dengan penelitian Irawan dkk.(2018),(18) bahwa persepsi masyarakat mengenai alur pelayanan bagi peserta JKN yang dirasakan sulit dan waktu tunggu yang lama untuk memperoleh layanan kesehatan dapat berdampak kepada berkurangnya minat masyarakat untuk memanfaatkan pelayanan kesehatan. Selain itu, prosedur pelayanan dan pendaftaran menjadi peserta rumit karena kurangnya sosialisasi 
yang diberikan akibatnya program JKN kurang dipahami oleh masyarakat. Adapun yang menyatakan bahwa sosialisasi terkait BPJS kesehatan sangatlah berpengaruh terhadap pemahaman hak peserta.(19)

Sikap baik masyarakat tentang BPJS Kesehatan sangat berpengaruh terhadap keikutsertaan masyarakat sebagai peserta BPJS Kesehatan.(20) Semakin masyarakat bersikap positif dan mendukung, maka kecenderungan masyarakat dalam memanfaatkan JKN akan semakin tinggi. Penelitian serupa membuktikan secara statistik bahwa responden dengan sikap mendukung terhadap BPJS Kesehatan memiliki kemungkinan berminat menjadi peserta JKN sebesar 13,4 kali lebih besar dari responden dengan sikap kurang mendukung.(21) Hasil penelitian menunjukan bahwa ada hubungan antara sikap dengan keputusan pekerja mandiri menjadi peserta JKN. Menurut peneliti hal ini karena baik dan buruknya sikap seseorang terhadap sesuatu akan mempengaruhi perilakunya dalam bertindak. Responden yang memutuskan menjadi peserta JKN memiliki sikap yang baik terhadap JKN dan mendukung adanya program JKN sedangkan responden yang tidak memutuskan menjadi peserta JKN memiliki sikap yang buruk terhadap JKN.

Fasilitas kesehatan merupakan sarana dan prasarana yang diberikan oleh penyedia layanan kesehatan kepada pasien JKN baik di tingkat pertama ataupun tingkat lanjutan. Hasil analisis menunjukkan bahwa pekerja mandiri yang tidak terdaftar menjadi peserta JKN dengan persepsi negatif terhadap fasilitas pelayanan kesehatan JKN paling banyak tidak menjadi peserta JKN. Artinya pekerja mandiri yang tidak memutuskan menjadi peserta JKN banyak yang menilai bahwa ketersediaan dan kondisi fasilitas kesehatan belum memadai. Hasil penelitian menunjukkan bahwa tidak ada hubungan antara persepsi fasilitas kesehatan dengan keputusan pekerja mandiri menjadi peserta JKN. Menurut peneliti, responden memutuskan mendaftar menjadi peserta JKN tidak melihat dari ketersediaan dan kondisi pelayanan kesehatan masyarakat tetapi lebih melihat pada kebutuhan mereka terhadap $\mathrm{JKN}$, karena walaupun masyarakat mendaftarkan diri menjadi peserta JKN ataupun tidak mendaftarkan menjadi peserta JKN, masyarakat akan tetap menggunakan fasilitas pelayanan kesehatan yang sama. Padahal, fasilitas fisik, perlengkapan dan tenaga merupakan hal yang penting bagi pasien karena apa yang dilihat dan dirasakannya akan mengubah persepsi.(22) Hal ini diperkuat dari hasil penelitian lainnya bahwa pelayanan fasilitas kesehatan dan pelayanan administrasi berpengaruh terhadap tingkat kepuasan peserta JKN-KIS baik secara parsial maupun simultan.(23)

Besarnya penghasilan yang diterima oleh seseorang akan mempengaruhi kemauan seseorang untuk mendaftar menjadi peserta asuransi kesehatan. Masyarakat yang mempunyai pendapatan yang lebih lebih tinggi, memutuskan menjadi peserta JKN karena mereka yang mempunyai penghasilan yang cukup akan mempertimbangkan dengan baik untuk mengikuti JKN. Berdasarkan hasil penelitian bahwa terdapat hubungan antara tingkat pendapatan dengan keputusan pekerja mandiri menjadi peserta JKN. Penelitian ini sejalan dengan penelitian sebelumnya yang membuktikan adanya hubungan penghasilan dengan keikutsertaan jaminan kesehatan.(24) Menurut peneliti terdapatnya hubungan antara pendapatan dengan keputusan menjadi peserta JKN karena masyarakat berasumsi bahwa untuk memutuskan menjadi peserta JKN harus memiliki penghasilan yang cukup karena setiap bulannya dituntut untuk melakukan pembayaran iuran JKN secara rutin. Hal itulah yang mengakibatkan responden yang mempunyai penghasilan yang kurang tidak begitu tertarik menjadi peserta JKN.

Dalam pencapaian UHC, salah satu hal yang perlu diperhatikan adalah aspek equity kesehatan pada kemudahan akses dan pemerataan pelayanan kesehatan sehingga penting sekali memahami dengan baik equity geografis dan equity social-ekonomi.(25) Pengaruh jarak rumah dengan fasilitas pelayanan kesehatan tak terlepas dari besarnya biaya yang digunakan serta waktu yang lama untuk menjangkau fasilitas kesehatan. Hasil penelitian 
menunjukkan bahwa pekerja mandiri yang tidak memutuskan menjadi peserta JKN adalah responden yang memiliki jarak tempuh ke fasilitas pelayanan kesehatan yang dekat dan tidak ada hubungan antara jarak tempuh fasilitas kesehatan dengan keputusan pekerja mandiri menjadi peserta JKN. Hal ini karena sebagian besar responden mempunyai jarak tempuh rumah yang dekat dengan fasilitas kesehatan yaitu $81,48 \%$.

Masyarakat yang mendapatkan dukungan keluarga kemungkinan besar akan memutuskan menjadi peserta JKN mandiri atau sebaliknya. Peran keluarga sebagai pendukung bagi anggotanya yang dapat berupa dukungan emosional seperti ungkapan empati, kepedulian dan perhatian.(26) Hasil penelitian diperoleh ada hubungan antara dukungan keluarga dengan keputusan pekerja mandiri menjadi peserta JKN di Kecamatan Indralaya Utara. Keluarga merupakan orang yang paling dekat dan yang pertama berperan dalam memberikan masukan dan motivasi terhadap seseorang ketika sedang berada dalam masalah termasuk keputusan menjadi peserta JKN. Dukungan keluarga dapat berupa dukungan informasi terkait JKN yaitu informasi mengenai iuran, cara mendaftar, tempat mendaftar, manfaat JKN. Dukungan informasi merupakan dukungan penting yang diberikan oleh keluarga terdekat dalam pengambilan tindakan untuk ikut serta menjadi peserta JKN.(27)

Adapun hasil penelitian menunjukkan tidak ada hubungan antara dukungan petugas dengan keputusan pekerja mandiri menjadi peserta JKN di Kecamatan Indralaya Utara. Menurut peneliti tidak adanya hubungan karena terbatasnya kegiatan sosialisasi tentang JKN dari petugas JKN di daerah tempat tinggal responden, yang artinya responden tidak mendapatkan dukungan yang baik dari petugas JKN. Adanya perlakuan yang baik dan penuh perhatian menjadi suatu daya tarik tersendiri dalam pemberian pelayanan kepada pasien. Hal ini memberikan kekuatan secara psikologis bagi pasien dan menumbuhkan motivasi untuk memanfaatkan layanan yang diberikan.(28) Dukungan petugas yang dimaksud dalam penelitian ini adalah peran petugas BPJS dan tenaga kesehatan pada program JKN dalam memberikan dorongan dan dukungan misalnya dalam hal pemberian informasi tentang JKN. Penelitian yang dilakukan oleh Siswoyo dkk.(2015),(29) tentang kesadaran pekerja sektor informal terhadap program jaminan kesehatan nasional, responden menunda untuk mendaftarkan diri menjadi peserta JKN disebabkan salah satunya karena kurangnya pengetahuan responden terhadap JKN karena tidak pernah mengikuti sosialisasi tentang JKN dan belum sepenuhnya memahami manfaat dari Jaminan kesehatan nasional.

\section{Kesimpulan}

Keputusan pekerja mandiri untuk menjadi peserta JKN di Kecamatan Indralaya Utara menunjukan terdapat hubungan yang signifikan dengan pengetahuan mengenai JKN, kepercayaan, persepsi mengenai JKN, sikap, pendapatan dan dukungan keluarga. Oleh karena itu BPJS Kesehatan sebaiknya lebih mengoptimalkan kegiatan sosialisasi melalui kerjasama dengan puskesmas-puskesmas dan tenaga kesehatan yang ada di puskesmas agar bisa mengaktifkan kader-kader masyarakat untuk menyebarkan informasi program JKN sekaligus mengajak untuk mendaftar JKN secara mandiri bagi golongan pekerja mandiri.

\section{Daftar Pustaka}

1. Menteri Kesehatan RI. Peraturan Menteri Kesehatan Republik Indonesia nomor 28 tahun 2014 tentang Pedoman Pelaksanaan Program Jaminan Kesehatan Nasional. Jakarta; 2014.

2. DPR RI. dan PR. Indonesia nomor 24 tahun 2011 tentang Badan Penyelenggara Jaminan Sosial. Jakarta; 2011.

3. DPR RI. dan PR. Peraturan Presiden Republik Indonesia nomor 111 tahun 2013 tentang Perubahan Atas Peraturan Presiden nomor 12 tahun 2013 tentang Jaminan Kesehatan. Jakarta; 2013. 
4. BPJS Kesehatan. Laporan Pengelolaan Program dan Laporan Keuangan Jaminan Sosial Kesehatan tahun 2017. Jakarta; 2019.

5. Pemerintah Kabupaten Ogah Ilir. LKIP:Laporan Kinerja Instansi Pemerintah Kabupaten Ogan Ilir Tahun 2017. Indralaya; 2018.

6. Misnaniarti. Analisis Kebijakan Pemerintah Daerah dalam Pengembangan 'Jaminan Sosial Kesehatan Sumatera Selatan Semesta' Menyambut Universal Health Coverage. Jurnal Kebijakan Kesehatan Indonesia. 2013;2(3):118-25.

7. Widhiastuti IAP PP Januraga, DN Wirawan. Hubungan Persepsi Manfaat dengan Kepesertaan JKN Secara Mandiri di Puskesmas I Denpasar Timur. Public Health and Preventive Medicine Archive. 2015;3(2):203-10.

8. Idris H. Analisis Triangle Kebijakan Publik Jaminan Kesehatan: Studi Kasus pada Sektor Informal di Indonesia. Jurnal IImu Kesehatan Masyarakat. 2017;8(3):135-44.

9. Naralita W 1 Iwan Stia Budi, Dian Safriantini. Peran Kemitraan Sektor Kesehatan dan Non Kesehatan dalam Perluasan Kepesertaan JKN di Kabupaten Banyuasin. Jurnal IImu Kesehatan Masyarakat. 2017;8(1):56-66.

10. Kurniawati W Riris Diana Rachmayanti. Identifikasi Penyebab Rendahnya Kepesertaan JKN pada Pekerja Sektor Informal di Kawasan Pedesaan. Jurnal Administrasi Kesehatan Indonesia. 2018;6(1):33-9.

11. Kusumaningrum A Muhammad Azinar. Kepesertaan Masyarakat dalam Jaminan Kesehatan Nasional Secara Mandiri. HIGEIA Journal of Public Health Research and Development. 2018;2(1):149-60.

12. Putro $G$ dan Iram Barida. Manajemen Peningkatan Kepesertaan dalam Jaminan Kesehatan Nasional pada Kelompok Nelayan Non Penerima Bantuan luran (Non PBI). Media Litbangkes. 2017;27(1):17-24.

13. Ernawati CT Dhina Uswatul. Hubungan Kepesertaan JKN Mandiri dengan Pendapatan, Pengetahuan, Persepsi, Akses, dan Kepercayaan Masyakat Suku Sakai di Desa Petani Kecamatan Mandau Kabupaten Bengkalis Tahun 2018. Jurnal Kebijakan Kesehatan Indonesia. 2019;8(1):25-9.

14. Ervina L Dian Ayubi. Peran Kepercayaan Terhadap Penggunaan Pengobatan Tradisional Pada Penderita Hipertensi di Kota Bengkulu. Perilaku dan Promosi Kesehatan. 2018;1(1):1-9.

15. Wardiha MW. Analisis Komparatif Peran Adat dan Kepercayaan dalam Peningkatan Kualitas Lingkungan Permukiman Berkaca pada Adat yang Ada di Permukiman Tradisional. Jurnal Presipitasi: Media Komunikasi dan Pengembangan Teknik Lingkungan. 2018;15(1):113-21.

16. Mutmainah NF. Identifikasi Faktor-Faktor yang Mempengaruhi Persepsi dan Partisipasi Masyarakat Kabupaten Bantul dalam Kepesertaan Program JKN-KIS. Jurnal Polinter Prodi IImu Politik. 2018;3(2):1-9.

17. Intiasari AD Laksono Trisnantoro, Julita Hendrartini. Potret Masyarakat Sektor Informal di Indonesia: Mengenal Determinan Probabilitas Keikutsertaan Jaminan Kesehatan Sebagai Upaya Perluasan Kepesertaan Pada Skema Non PBI Mandiri. Jurnal Kebijakan Kesehatan Indonesia. 2015;4(4):126-32.

18. Irawan B Asmaripa Ainy. Analisis Faktor-Faktor yang Berhubungan dengan Pemanfaatan Pelayanan Kesehatan pada Peserta Jaminan Kesehatan Nasional di Wilayah Kerja Puskesmas Payakabung, Kabupaten Ogan llir. Jurnal IImu Kesehatan Masyarakat. Jurnal IImu Kesehatan Masyarakat. 2018;9(3):189-97.

19. Laili N. Hubungan Sosialisasi Program BPJS terhadap Pemahaman tentang Hak Peserta BPJS Kesehatan di RSUD Syarifah Ambami Rato Ebu Bangkalan. DIA, Jurnal Administrasi Publik. 2014;12(1):27-38.

20. Prasetyo B. Faktor-Faktor yang Berhubungan Dengan Kepesertaan Badan Penyelenggara Jaminan Sosial Kesehatan Mandiri pada Masyarakat Kelurahan Tanjung Puri Tahun 2015. Wawasan Kesehatan. 2016;3(1):81-9.

21. Melinda AS Antono Suryoputro. Faktor-Faktor yang Berhubungan dengan Minat Masyarakat dalam Keikutsertaan BPJS Mandiri di Kecamatan Bener Kabupaten Purworejo. Jurnal Kesehatan Masyarakat. 2016;4(4):86-93.

22. Siswati S. Kualitas Pelayanan Kesehatan dengan Kepuasan Pasien BPJS di Unit Rawat Inap RSUD Kota Makassar. Jurnal Media Kesehatan Masyarakat. 2015;11(3):174-83. 
23. Wijaya T Icha Fajriana. Tingkat Kepuasan Peserta JKN-KIS BPJS Kesehatan di Kota Palembang. Jurnal Ekonomi Keuangan dan Bisnis Islam. 2018;13(2):81-92.

24. Werdani KE Salma Binti Purwaningsih, dan Purwanti. Keikutsertaan Kepala Keluarga Desa Tegalsari Ponorogo dalam Jaminan Kesehatan Nasional. Jurnal Manajemen Informasi Kesehatan Indonesia. 2017;5(1):85-91.

25. Yandrizal H Desri Suryani. Analisis Ketersediaan Fasilitas dan Pembiayaan Kesehatan pada Pelaksanaan Jaminan Kesehatan Nasional di Provinsi Bengkulu. Jurnal Kebijakan Kesehatan Indonesia. 2014;3(4):219-26.

26. Intarti WD Siti Nur Khoriah. Faktor-Faktor yang Mempengaruhi Pemanfaatan Posyandu Lansia. Journal of Health Studies. 2018;2(1):110-22.

27. Nadiyah H Subirman dan Dina Lusiana S. Faktor-Faktor yang Berhubungan dengan Kepesertaan Progra JKN di Wilayah Kerja Puskesmas Remaja Kota Samarinda. Jurnal Kebijakan Kesehatan Indonesia. 2017;6(2):66-72.

28. Rumengan DSS JML Umboh,GD Kandou. Faktor-Faktor yang Berhubungan dengan Pemanfaatan Pelayanan Kesehatan Pada Peserta BPJS Kesehatan di Puskesmas Paniki Bawah Kecamatan Mapanget Kota Manado. Jurnal Kesehatan Masyarakat Unsrat. 2015;5(1):88-100.

29. Siswoyo BE Yayi Suryo Prabandari, Yulita Hendrartini. Kesadaran Pekerja Sektor Informal terhadap Program Jaminan Kesehatan Nasional di Provinsi Daerah Istimewa Yogyakarta. Jurnal Kebijakan Kesehatan Indonesia. 2015;4(4):118-25. 